\title{
LONG TERM AIR QUALITY ANALYSIS IN REFERENCE TO THERMAL POWER PLANTS USING SATELLITE DATA IN SINGRAULI REGION, INDIA
}

\author{
H.K. Romana ${ }^{1 *}$, R.P. Singh ${ }^{2}$, D.P. Shukla ${ }^{3}$ \\ ${ }^{1}$ School of Engineering, IIT Mandi, Himachal Pradesh, India - d19010@ students.iitmandi.ac.in \\ ${ }^{2}$ Schmid College of Science and Technology, Chapman University Orange, CA 92866, USA rsingh@ chapman.edu \\ ${ }^{3}$ School of Engineering, IIT Mandi, Himachal Pradesh, India- dericks@ iitmandi.ac.in
}

Commission III, WG III/8

KEYWORDS: Air quality; NASA GES data; Anthropogenic activities; Thermal Power Plants; Singrauli region.

\begin{abstract}
The exponentially growing population and related anthropogenic activities have led to modifications in local environment. The change in local environment, evolving pattern of land use, concentrations of greenhouse gases and aerosols alter the energy balance of our climate system. This alteration in climate is leading to pre-mature deaths worldwide. This study analyses the air quality of Singrauli region, Madhya Pradesh, India for the past 15 years. Otherwise known as Urjanchal "the energy capital" of India has been declared as critically polluted by CPCB. The study provides an updated list of thermal power plants in the study area and their emission effects on the local environment. The pollutants analyzed in the study are carbon dioxide, methane, nitrogen dioxide, Sulphur dioxide and particulate matter. Long term remotely sensed data was obtained from NASA Giovanni for past 15 years. Statistical analysis is used to characterize seasonal and annual variations of trace gases in the study area. The study concluded that Methane, Carbon dioxide, Nitrogen dioxide and Sulphur dioxide are on an increasing trend with an average rate of 1.03, 0.99, 2.15 and 1.09 annually. Secondly, Methane \& $\mathrm{SO}_{2}, \mathrm{PM}_{2.5} \& \mathrm{NO}_{2}, \mathrm{PM}_{10} \& \mathrm{NO}_{2}, \mathrm{CO}_{2}$ \& Methane and $\mathrm{PM}_{2.5} \& \mathrm{PM}_{10}$ have strong correlations with a $95 \%$ significance. Furthermore, Methane, $\mathrm{SO}_{2}$ and $\mathrm{CO}_{2}$ exhibit cyclic variation with change in season. The study also indicated that maximum aerosols present in the study area are a result of anthropogenic activities.
\end{abstract}

\section{INTRODUCTION}

Air pollution is heeded as a damnation for global environment. In addition to natural sources contributing to pollution, increased industrialization with inter-twined economic, technologic and political change aggravates the burden. Air pollution encases numerous trace gases including; Carbon dioxide $\left(\mathrm{CO}_{2}\right)$, Nitrogen dioxide $\left(\mathrm{NO}_{2}\right)$, Sulphur dioxide $\left(\mathrm{SO}_{2}\right)$, particulate matter $\left(\mathrm{PM}_{2.5}\right.$ \& $\mathrm{PM}_{10}$ ) carbon monoxide (CO) (Chen et al.,2007). Each pollutant may originate from different sources, however, are interlinked with fuel combustion and/or industrial activities. In addition to the crippling effect on the environment, pollutants have an adverse effect on human health, crops and ecosystem. In the year 2012, 3 million deaths were attributed to air pollution globally (WHO, 2016). Henceforth, it is pivotal to monitor the air quality and take informed decisions regarding its impact on the environment.

Air pollution has become a transnational issue, compelling organizations to work on a united front. The exponential rise in industrialization during past few decades have resulted in elevated concentration of greenhouse gases worldwide. While small concentration of greenhouse gases favor in warming the earth, the escalated concentration from anthropogenic activities, intensifies their effect. At a global level, industrialization established a shift in the air quality worldwide during mid- $18^{\text {th }}$ century. A rapid increase in $\mathrm{SO}_{2}$ is observed from $1850(1.36 \mathrm{M}$ tonnes) to 1980 (71.25 M tonnes) in Europe. Similar patterns are seen for North and South America peaking at $30.46 \mathrm{M}$ tonnes and $8.76 \mathrm{M}$ tonnes respectively in 1980 . Further, the $\mathrm{SO}_{2}$ emission follows a decreasing trend. On the other hand, in Asia and Africa, the $\mathrm{SO}_{2}$ emissions are increasing. Similarly, carbon dioxide emission annual trends grew much earlier in Europe and America than other regions around the world (OECD, 2014; Klimont et al., 2013). At present, China, is the lead emitter of carbon dioxide followed by United States, European Union, India and United Kingdom (Ritchie and Roser, 2020). Moreover, $49.04 \%$ of the global $\mathrm{CO}_{2}$ emissions results from electricity and heat production sector. Emission of distinct pollutants and particulate matter (PMs), owing to industrial development, heavy motor vehicle uses and greater population density, has grown rapidly in demographic areas (Moorthy et al., 2016)

Globally, about $2 / 3^{\text {rd }}$ of total electricity generated is produced from thermal power plants. It has been cogent that countries with strict emission regulations have low greenhouse gases emission. For instance, $\mathrm{NO}_{\mathrm{x}}$ emissions have reduced by $50 \%$ in 2000 as compared to past decade in 6 states along Ohio River region comprising of West Virginia, Ohio, Illinois, Pennsylvania, Kentucky, Indiana (Frost et al., 2006). Furthermore, average NOx intensity in US is calculated to be $1.09 \mathrm{~g} / \mathrm{kWh}$ during 2010 (Tian et al., 2013). On the other hand, models predict 1.7-1.8 times increase of $\mathrm{CO}_{2}$ emissions by 2030 and 2.6-2.7 times by 2050 in Russia. Similarly, an increase of $5.4 \% \mathrm{CO}_{2}$ has been estimated between 1990-2000 and an increase of $48.4 \%$ has been anticipated by 2010 (Hammons, 2006). An inventory study in China suggested that a coal fired thermal power plant emits 400 $450 \mathrm{mg} / \mathrm{m}^{3} \mathrm{NO}_{\mathrm{x}}$ and $600-700 \mathrm{mg} / \mathrm{m}^{3} \mathrm{SO}_{2}$ (Liu and Wen, 2012). In another study, the authors also concluded that maximum greenhouse emissions result from coal fed thermal power plants. It was estimated that a total of $753890 \mathrm{kt}$ of $\mathrm{NO}_{\mathrm{x}}$ was emitted from 31 Chinese provinces during the year 2010 (Tian et al., 2013). About 110 Ktons/years of $\mathrm{PM}_{2.5}$ and 2300 Ktons of $\mathrm{NO}_{\mathrm{x}}$ annually was emitted from coal based thermal power plants during 2010 (Wang et al., 2012).

In India, Sulphur dioxide emissions continue to grow and has become the world's second largest emitter after China (Smith et al., 2011). For instance, $\mathrm{SO}_{2}$ emissions have increased from 1.95

\footnotetext{
* Corresponding Author
} 
million tonne (1878) to 2.47 billion tonne (2017) in India (Quéré et al., 2017). Similarly, methane emissions have hiked from 398.21 million tonne (1970) to 636.40 million tonne (2012) (Ritchie and Roser, 2020). It has been observed that $\mathrm{CO}_{2}$ emissions have increased from 438.95 million tonnes (1990) to 1.30 billion tonnes (2010) (Oliver et al., 2016)

Furthermore, there are more than 100 thermal power plants across the country generating $66 \%$ of electricity, with coal as a primary fuel choice accounting for $50-55 \%$ of total power generation (Chikkatur et al., 2011; WISE, 2012; Prayas, 2013). However, such power generation implies a huge cost to environment (Guttikunda and Jawahar, 2014).

In this paper, the temporal variation of trace gases and particulate matter is analyzed using satellite data in Singrauli district, Madhya Pradesh, India. Although, ground based measurement techniques are more accurate in monitoring air quality, it has two major disadvantages. Firstly, the ground monitoring stations are sparsely and unevenly distributed in the area. Secondly, the uneven distribution of monitoring stations restricts a study area that can be analyzed. On the other hand, satellite data gives a broad spatial and temporal coverage and is now a future tool to understand national impacts of air quality (Lee et al., 2012). Furthermore, high quality ground-based measurements are lacking in developing countries like India and remote sensing techniques can provide coverage for larger areas. (Brauer et al. 2012) In other words, satellite data is a comprehensive information, visualization and validation to field measurements of air quality (Engel-Cox et al., 2004). Henceforth, an attempt has been made to monitor air quality using remotely sensed data.

This study aims to monitor greenhouse emissions in the study area for the past 15 years. The trace gases focused are carbon dioxide, nitrogen dioxide, methane, particulate matter and Sulphur dioxide. The remotely sensed data is used to visualize trend of trace gases in reference to installation of thermal power plants. Furthermore, a seasonal variation has been analyzed in the study to understand the variation of pollutant concentration. This will provide insight to cycle of pollutants and can be utilized to modify guidelines for operations of a coal fed thermal plant. Also, a correlation among the focused trace gases has been estimated in order to evaluate the dependency among trace gases. The visualization provided in the study will help understand the long-term and short-term variations of a pollutant. Additionally, this analysis will provide assistance to policy makers to enforce mitigation measures in the power sector to improve air quality.

\section{MATERIAL AND METHODS}

\subsection{Study Area}

The study site is located in Singrauli region of Madhya Pradesh, India. The study area is rich in natural and mineral resources, however, was covered with dense forests and inhospitable terrain in ancient times. Spread over a total area of $5675 \mathrm{sqkm}$, Singrauli has a population of $1,178,273$. A $2^{\circ} \mathrm{X} 2^{\circ}$ grid $[23 \mathrm{E}, 81 \mathrm{~N}, 25 \mathrm{E}$, $83 \mathrm{~N}$ ] was chosen, to cover whole Singrauli area. It has warm and temperate climate; The average annual rainfall is $1014 \mathrm{~mm}$. Singrauli area is the major power hub of the country. The availability of rich natural resources and raw material feeds the need of thermal power plant, aluminium industry, chemical industry, mining industry, and stone crushers established in this region. Due to the industrialization of the area environmental problems have been reported since few decades. CPCB and Ministry of Environment and forest after detailed environmental study have identified Singrauli as a critically polluted area since the year 1991 There are many Thermal Power plants in this region generating nearly 19284 MW of electricity (Table 2). Emissions from thermal power plants and coal mines are the major sources of pollution in the study area.

\subsection{Data Used and Analysis}

Data sets used in this work were downloaded from the Giovanni online data system, developed and maintained by the NASA GES DISC as described in table 1.

Aerosol optical depth is the quantitative estimate of the amount of aerosol present in the atmosphere and angstrom exponent is the measure of optical thickness of an aerosol. A scatter plot of AOD vs AE is used in this study to establish type of aerosols in atmosphere. Greenhouse gases such as nitrogen dioxide, sulphur dioxide, carbon dioxide and methane, absorbs heat radiations to keep the planet warm. However, anthropogenic activities have rapidly increased their concentration and monitoring and mitigation measures are need of the hour. Particulate matter are small particles such as dirt, soot or smoke. $\mathrm{PM}_{10}$ and $\mathrm{PM}_{2.5}$ are the particles smaller than 10 micrometers and 2.5 micrometers respectively.

Trend analysis was performed in order to visualize and characterize the long-term and short-term variations of pollutant concentration. Cyclic variation of pollutants in pre-monsoon, monsoon, post-monsoon and winter seasons has been visualized. The trend of change has been compared with each new installation of a thermal power plant to anticipate the effect of new thermal power plant on pollutant concentration. Furthermore, correlations among different pollutants were estimated.

Table 1: Data source

\begin{tabular}{|c|c|c|c|}
\hline S.No. & Trace Gas & Satellite & Spatial Resolution \\
\hline 1 & AOD & \multirow{2}{*}{ MODIS } & $1^{\circ} \mathrm{X} 1^{\mathrm{o}}$ \\
\hline 2 & $\mathrm{AE}$ & & $1^{\circ} \mathrm{X} 1^{\circ}$ \\
\hline 3 & $\mathrm{SO} 2$ & \multirow{2}{*}{ OMI } & $0.25^{\circ} \times 0.25^{\circ}$ \\
\hline 4 & $\mathrm{NO} 2$ & & $0.25^{\circ} \times 0.25^{\circ}$ \\
\hline 5 & $\mathrm{CO} 2$ & \multirow{2}{*}{ AIRS } & $2^{\circ} \times 2.5^{\circ}$ \\
\hline 6 & $\mathrm{CH} 4$ & & $1^{\circ} \mathrm{X} 1^{\mathrm{o}}$ \\
\hline 7 & $\begin{array}{l}\text { PM } 2.5 \text { and } \\
\text { PM10 }\end{array}$ & $\mathrm{CPCB}$ & $\begin{array}{c}\text { Ground } \\
\text { Observation }\end{array}$ \\
\hline
\end{tabular}

\section{RESULTS AND DISCUSSION}

Sulphur content in Indian coal $(0.2-0.7 \%)$ is lower than the coal used in western countries. On combustion, most of the Sulphur is converted to $\mathrm{SO}_{2}$. On the other hand, emission of $\mathrm{NO}_{2}$ depends upon the design and condition of thermal power plant. Additionally, the high silica and alumina content in Indian coal increases ash resistivity and reduce the collection efficiency at the electrostatic precipitators. Henceforth, coal powered thermal plants act a large point source for $\mathrm{SO}_{2}$ and $\mathrm{NO}_{2}$ emissions. Details of thermal power plants installed in the study area are given in table 2 .

Table 2: Thermal power plant details.

\begin{tabular}{|l|l|l|l|}
\hline S. No & Name & Location & $\begin{array}{l}\text { Capacity } \\
(\mathbf{M W})\end{array}$ \\
\hline 1 & NTPC & Vindhyachal & 2000 \\
\hline 2 & NTPC & Shaktinagar & 2000 \\
\hline & NTPC & Rihand & 3000 \\
\hline 3 & Essar & Sasan & 1200 \\
\hline 4 & Reliance & Sasan & 3940 \\
\hline 5 & Jaypee & Nigre & 1320 \\
\hline 6 & Hindalco & Baragawon & 900 \\
\hline 7 & UPRVUNL & Anpara & 2630 \\
\hline 8 & UPRVUNL & Obra & 1094 \\
\hline 9 & Lanco & Anpara & 1200 \\
\hline
\end{tabular}


According to Environment protection amendment rules India, 2015, the emission standard limits of $\mathrm{SO}_{2}, \mathrm{NO}_{\mathrm{x}}$ and $\mathrm{PM}\left(\mathrm{mg} / \mathrm{m}^{3}\right)$ for new and old thermal power are described in table 3

Table 3: Standard emission limits for existing and new thermal power plants $\left(\mathrm{mg} / \mathrm{m}^{3}\right)$

\begin{tabular}{|c|c|c|c|c|c|}
\hline \multicolumn{2}{|c|}{$\mathrm{SO}_{2}$} & \multicolumn{2}{c|}{$\mathrm{NO}_{\mathrm{x}}$} & \multicolumn{2}{c|}{ PM } \\
\hline Existing & New & Existing & New & Existing & New \\
\hline $200-600$ & 100 & $300-600$ & 100 & $50-100$ & 30 \\
\hline
\end{tabular}

As described in the literature, thermal power plants account for $15 \%$ of $\mathrm{PM}_{2.5}, 30 \%$ of $\mathrm{NO}_{\mathrm{x}}$ and $50 \%$ of $\mathrm{SO}_{2}$ emitted in the atmosphere (GAINS, 2012). Similar results were reported for thermal power plants in and around Delhi. A study conducted near thermal power plants of Singrauli concluded high BC concentration $>200 \mu \mathrm{g} / \mathrm{m}^{3}$ with peaks during early morning and evening hours, compared to the outside domain of the study region (Singh et al., 2018).

In this study, the change in trace gases levels are attributed with respect to thermal power plants. The straight lines shown in the figure 1 mark the start of a new thermal power plant in study area. As a new thermal power plant is installed, it takes a period of 68 months to attain its full capacity. As attributed from figure 1, the concentrations of Methane, $\mathrm{SO}_{2}$ and $\mathrm{CO}_{2}$ increases after a new TPP is introduced. Although, there were no new TPPs introduced after 2017, however, the collective effect of all the TPPs and limited emission control techniques affect the trace gases. It is evident that before the year $2007, \mathrm{CO}_{2}$ increased at a linearly. However, after 2012, $\mathrm{CO}_{2}$ increased more steeply. Similarly, $\mathrm{CH}_{4}, \mathrm{NO}_{2}$ and $\mathrm{SO}_{2}$ have elevated rate after 2012. The long-term and short-term changes of individual pollutants is explined below.

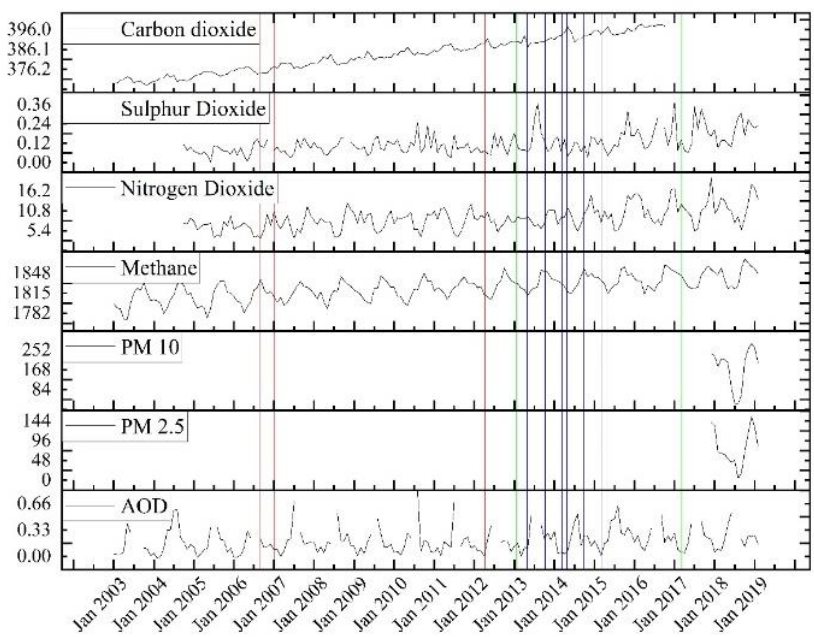

Fig 1: Trend of trace gases under observation. The straight lines in the figure mark the installation of new thermal power plant.

The Red lines label for NTPC, Green for Essar, Blue for Reliance and Orange for Hindalco.

\subsection{Carbon dioxide}

Before industrialization, $0.03 \%$ of earth's atmospheric volume was comprised of carbon dioxide. However, as a result of fossil fuel burning it has increased by $25 \%$. The resident time of stable $\mathrm{CO}_{2}$ molecule is 3 years in the troposphere and more than 100 years in atmosphere (Raghuvanshi et al., 2006). This increased $\mathrm{CO}_{2}$ concentration in the atmosphere has caused unprecedented climate abnormalities. This study has analyzed trend of $\mathrm{CO}_{2}$ since the year 2003. It is evident from figure 2 that $\mathrm{CO}_{2}$ content has increased linearly from a minimum value of $374.10 \mathrm{ppm}$ in January 2003 till a maximum value of 403.68 ppm in June 2016. Every year since 2003 the annual rate of increase is approximately 0.99 times. Similarly, the overall $\mathrm{CO}_{2}$ emission in the country has increased from $120.6 \mathrm{M}$ tonnes in 1960 to 2238.4 $\mathrm{M}$ tonnes in 2014, approximately an increase of 19 times.

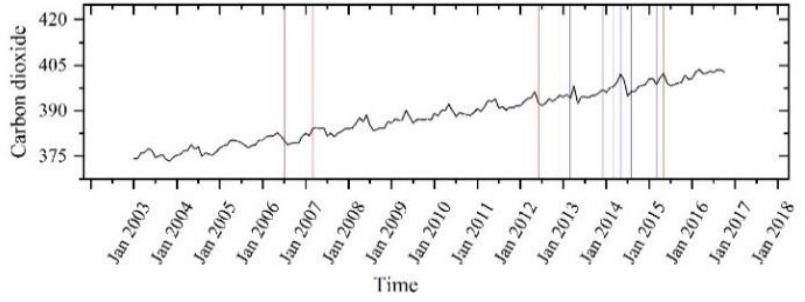

Fig. 2: Trend of Carbon dioxide.

Considering short term variation, $\mathrm{CO}_{2}$ shows a cyclic variation annually as shown in figure 2 . It is observed that in $2003, \mathrm{CO}_{2}$ increases from a minimum value of $374.10 \mathrm{ppm}$ in January till a maximum value of $377.51 \mathrm{ppm}$ in May. It then decreases to a value of $373.35 \mathrm{ppm}$ in November. $\mathrm{CO}_{2}$ obtains a maximum value of $378.89 \mathrm{ppm}$ in May 2004. It is evident from the figure 2 that higher concentrations are observed during the months of May, June and July. On the other hand, the lower concentrations are observed during August and September. This can be attributed to rise of temperature during the months of April-June. Similar results were observed in a study of Gujarat (74 million tons), Maharashtra (94.6 million tons), Uttar Pradesh (74 million tons), Andhra Pradesh (62.8 million tons) and Chattisgarh (58.9). (Guttikunda and Jawahar, 2014). Furthermore, $\mathrm{CO}_{2}$ emission has increased 5.6\% from Indian thermal power plants during 20012010 (Mittal, 2012).

\subsection{Methane}

Methane is emitted from active, inactive, underground or surface coal mines. It is also emitted from the post-mining activities such as coal processing, storage and transportation. Methane is a prominent volatile organic compound, contributing to formation of ozone. In India, methane emissions have increased from 31.8 M tonnes (1990) to $73.4 \mathrm{M}$ tonnes (2010) due to energy production alone(Ritchie and Roser, 2020. Literature has also suggested that methane emissions have increased at an rate of 1 percent annually(Raghuwanshi et al.,2006). In this section the methane emissions of Singrauli region since 2003 have been studied. It is clear from figure 3 that the emissions have increased from $1786.99 \mathrm{ppbv}$ (2003) to $1887.79 \mathrm{ppbv}$ (2018).

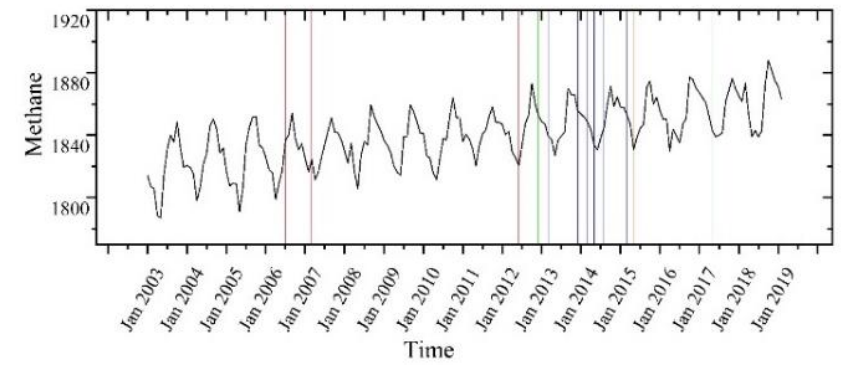

Fig. 3: Trend of Methane.

Conjointly, methane concentration shows a cyclic variation, where the minimum concentrations were observed during the month of April, May and June. On the contrary, the maximum concentrations were observed during September and October. 


\subsection{Nitrogen dioxide}

Literature suggest that anthropogenic activities have progressed highly in emitting $\mathrm{NO}_{2}$. This study shows variation of $\mathrm{NO}_{2}$ over time since 2003 as described in figure 4 . It is distinct that the concentration of $\mathrm{NO}_{2}$ has increased over the span of time. It is established that due to strong vertical mixing and higher solar radiation, concentrations are higher during summer. On the other hand, due to stable thermal stability in winter, the $\mathrm{NO}_{2}$ concentration increases significantly. The same can be seen from figure 4 where the minimum concentration values are observed during the months of July, August and September. On the other hand, the maximum values were observed in the months of November and December. Similarly, elevated emissions were observed in Andhra Pradesh (187500 tons), Chattisgarh (172500 tons), Gujarat (220000 tons), Maharashtra (278500 tons) and Uttar Pradesh (235500 tons) (Guttikunda and Jawahar, 2014). In an another study, it was estimated that during the period 2005$2014 \mathrm{NO}_{2}$ emissions have increased by $24.9 \%$ in Chennai, $6.13 \%$ in Delhi and $16.8 \%$ in Hyderabad (Duncal et al., 2015).

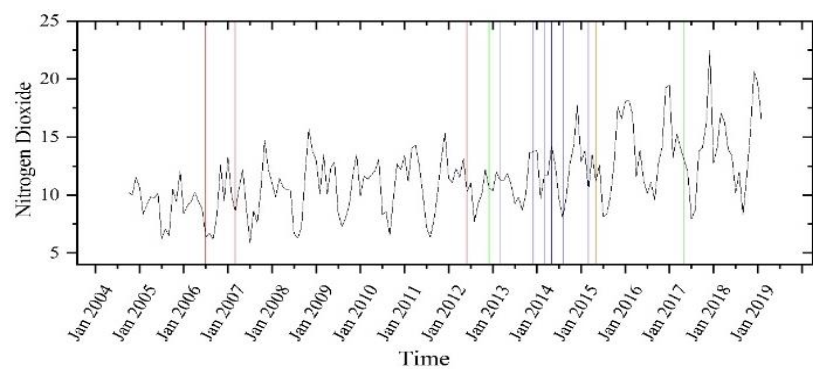

Fig. 4: Trend of Nitrogen dioxide.

\subsection{Sulphur dioxide}

Sulphur dioxide has a major influence on climate change, as, it is responsible for acid rain formation. (Menz and Seip, 2004). Other than energy sector, its emission depends on economic development. According to IPCC, global $\mathrm{SO}_{2}$ trend will decline with decrease in development in future decades. In India, $\mathrm{SO}_{2}$ levels have increased at an average rate of 1.05 since 2000 .

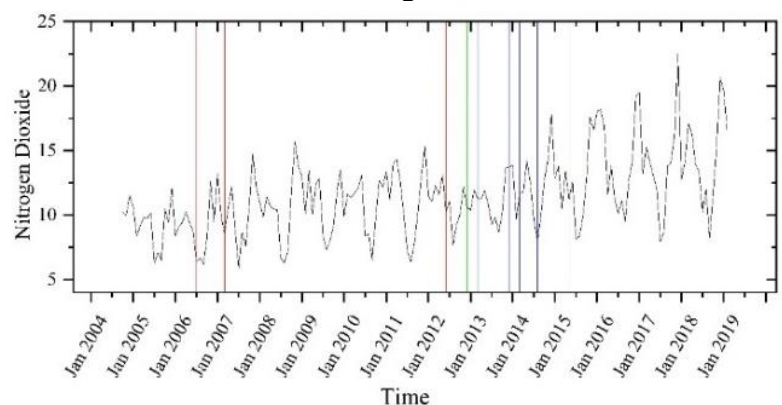

Fig 5: Trend of Sulfur dioxide.

The concentration of $\mathrm{SO}_{2}$ over the period of last 15 years is shown in figure 5 . The concentration has increased by 2.17 times. Furthermore, from the year 2007 till 2011, SO 2 levels had an increasing trend. The trend follows a cyclic pattern with decrease and increase in alternate years. On the other hand, there is no cyclic variation in the concentration of $\mathrm{SO}_{2}$ within a year, i.e. no seasonal patterns are observed. It has been documented in other studies that $\mathrm{SO}_{2}$ emissions have risen from 2.5 million tons (2001) to 3.8 million tons (2009), with an average annual rate of 169.39 thousand tons in India. Similarly, higher amount of emissions was observed in Andhra Pradesh (199500 tons), Chattisgarh (187000 tons), Gujrat (214000 tons), Maharashtra
(300500 tons) and Uttar Pradesh (235500 tons) (Guttikunda and Jawahar, 2014).

\subsection{Aerosol Optical Depth and Angstrom Exponent}

Aerosol optical depth (AOD) is a measure of the extinction of the solar beam by dust and haze. In other words, particles in the atmosphere (dust, smoke, pollution) can block sunlight by absorbing or scattering the light. Type of aerosol can be determined with the help of Angstrom exponent and AOD scatter plot. According to the author, if AOD is less than 0.9 and AE is greater than 0.9, the aerosols are categorized as Anthropogenic aerosols. Similarly, AOD $(>0.9)$ and AE $(>1)$, biomass burning aerosols, (AOD, AE) $(<0.7,<0.9)$, polluted continental and (AOD, AE) (>0.7, <0.6) dust aerosols (Tiwari et al., 2017). Angstrom exponent is a parameter that describes the relationship between optical thickness of an aerosol and wavelength of the light. It is inversely related to average size of the particles, therefore, the smaller the particle the larger the exponent.

Originated from both natural and anthropogenic activities, particulate matter in India, earlier, were mainly dust and carbonaceous compounds (Monks et al., 2009). However, emissions from fossil fuels and gigantic industries elevate atmospheric aerosols over Northern and Western India (Reddy and Venkataraman, 2002). The scatter plot of MODIS derived $\mathrm{AOD}$ and $\mathrm{AE}$ over the study area are reported in figure 6. It can be attributed, that the maximum number of aerosols reported can be classified under anthropogenic aerosols (figure 6).

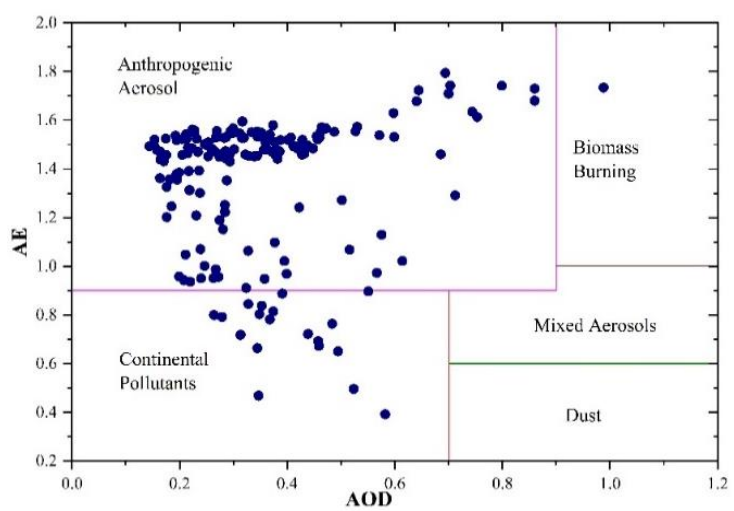

Fig. 6: Types of aerosols based on optical thickness.

\subsection{Correlation Analysis.}

The emitted greenhouse gases have individual residential period in the atmosphere, before there are removed. However, at the end of their residential period, few get oxidized and act as successor or pre-cursor of the other. Hence, increase in concentration of one trace gas can cause increase or decrease of the other. For instance, every molecule of methane has an 8 -year residue period before its oxidation into $\mathrm{CO}_{2}$ and water molecule. Similarly, 30-40\% of particulate matter are secondary, produced from conversion of gaseous $\mathrm{SO}_{2}$ and $\mathrm{NO}_{x}$ into aerosol sulphates and nitrates. In this study, table 4 represents correlation among the observed pollutant gases. 
Table 4: correlation matrix of trace gases

\begin{tabular}{|c|c|c|c|c|c|c|c|}
\hline & $\mathrm{AOD}$ & $\mathrm{SO}_{2}$ & $\mathrm{NO}_{2}$ & $\begin{array}{c}\text { Metha } \\
\text { ne }\end{array}$ & $\mathrm{PM}_{2.5}$ & $\mathrm{PM}_{10}$ & $\mathrm{CO}_{2}$ \\
\hline $\mathrm{AOD}$ & 1 & & & & & & \\
\hline $\mathrm{SO}_{2}$ & 0.093 & 1 & & & & & \\
\hline $\mathrm{NO}_{2}$ & 0.55 & 0.093 & 1 & & & & \\
\hline $\mathrm{CH}_{4}$ & -0.231 & 0.593 & 0.093 & 1 & & & \\
\hline $\mathrm{PM}_{2.5}$ & -0.236 & 0.385 & 0.599 & 0.423 & 1 & & \\
\hline $\mathrm{PM}_{10}$ & 0.016 & 0.363 & 0.665 & 0.478 & 0.824 & 1 & \\
\hline $\mathrm{CO}_{2}$ & 0.199 & 0.281 & 0.468 & 0.482 & NA & NA & 1 \\
\hline
\end{tabular}

The co-relation values thus obtained are at $95 \%$ and high significance level. Hence, it is articulate that; Methane \& $\mathrm{SO}_{2}$, $\mathrm{PM}_{2.5} \& \mathrm{NO}_{2}, \mathrm{PM}_{10} \& \mathrm{NO}_{2}, \mathrm{CO}_{2}$ \& Methane and $\mathrm{PM}_{2.5} \& \mathrm{PM}_{10}$ have strong correlations at significance level higher than $95 \%$. Since majority of particulate matter comprises of sulphates and nitrates, the concentration of $\mathrm{NO}_{2}$ and $\mathrm{SO}_{2}$ affect its concentration. Similarly, as methane oxidizes into carbon dioxide therefore, have a strong correlation.

\section{CONCLUSION}

In India, over 100 coal powered thermal power plants remain the main source for electricity generation. They act as a large point source for pollution in the country detrimenting the environemnt and human health. The new standards aim to reduce emissions considerably, however, this study shows that the concentration of gases are still on an increasing trend. The analysis has following conclusion

- Methane, $\mathrm{CO}_{2}, \mathrm{NO}_{2}$ and $\mathrm{SO}_{2}$ are on an increasing trend with an average rate of 1.03, 0.99, 2.15 and 1.09 annually.

- $\mathrm{CO}_{2} \& \mathrm{SO}_{2}, \mathrm{PM}_{10} \& \mathrm{PM}_{2.5}, \mathrm{PM}_{10} \& \mathrm{NO}_{2}$ and $\mathrm{CO}_{2} \& \mathrm{NO}_{2}$ have a co-relation at $99 \%$ significance.

- Methane, $\mathrm{SO}_{2}$ and $\mathrm{CO}_{2}$ exhibit cyclic variation with change in season. The maximum concentrations of methane, Sulphur dioxide and carbon dioxide are observed during post monsoon season. On the other hand, the minimum values of methane are observed during monsoon season, whereas, minimum concentrations of $\mathrm{SO}_{2}$ and $\mathrm{CO}_{2}$ are attributed during pre-monsoon season.

- Scatter plot of aerosol optical depth and angstrom exponent indicates that maximum aerosols present in the study area are result of anthropogenic activities.

- Thermal power plants act as a stationary source of emission. With every new coal fired thermal power plant the air quality has decreased in the study area.

\section{REFERENCES}

Brauer M., Amann M., Burnett R.T., et al., 2012. Assessment for Estimation of the Global Burden of Disease Attributable to Outdoor Air Pollution. Environ. Sci. Technol. 46, 652-660.

Chen T. M., Gokhale J., Shofer S. and Kuschner W. G.,2007. Outdoor Air Pollution: Nitrogen Dioxide, Sulfur Dioxide, and Carbon Monoxide Health Effects. J. Am. Med. Sci. 333(4), 249256.

Chikkatur, A.P., Chaudhary, A., Sagar, A.D., 2011. Coal power impacts, technology, and policy: connecting the dots. Annu. Rev. Environ. Resour. 36, 101-138.

Deguillaume, L., Leriche, M., Amato, P., et al., 2008. Microbiology and atmospheric processes: chemical interactions of primary biological aerosols. Biogeosciences 5, 1073-1084.
Duncan B. N., Lamsal L.N., Thompson A. M., et al., 2015. A space-based, high-resolution view of notable changes in urban NOx pollution around the world (2005-2014). J. Geophys. Res: Atm. 121, 976-996.

Engel-Cox J.A., Holloman C.H., Coutant B.W. and Hoff R.M.,2004. Qualitative and quantitative evaluation of MODIS satellite sensor data for regional and urban scale air quality. Atm. Environ. 38, 2495-2509.

Frost, G. J., et al. (2006), Effects of changing power plant NOx emissions on ozone in the eastern United States: Proof of concept, J. Geophys. Res.,111.

GAINS, 2012. Greenhouse Gas and Air Pollution Interactions and Synergies - South Asia Program. International Institute of Applied Systems Analysis, Laxenburg, Austria.

Guttikunda S.K. and Jawahar P., 2014. Atmospheric emissions and pollution from the coal-fired thermal power plants in India. Atmos. Environ. 92, 449-460.

Hammons T.J.,2006, Impact of electric power generation on green house gas emissions in Europe: Russia, Greece, Italy and views of the EU Power plant supply industry- a critical analysis. Electric Power and Energy Systems, 28, 548-564.

Indian Network for Climate Change Assessment (INCCA), India: Greenhouse Gas Emissions 2007, Ministry of Environment \& Forests, India, 2010.

International Energy Agency (IEA), 2008. World Energy Outlook.

IPCC. 2019, Refinement to the 2006 IPCC Guidelines for National Greenhouse Gas Inventories.

Klimont, Z; Smith S. J. and Cofala J., 2013. The last decade of global anthropogenic sulfur dioxide: 2000-2011 emissions. Environmental Research Letters, 8,1

Lee H.J., Coull B.A.,Bell M.L. and Koutrakis P.,2012. Use of satellite-based aerosols optical depth and spatial clustering to predict ambient $\mathrm{PM}_{2.5}$ concentrations. Environ. Res. 118, 8-15.

Liu X. and Wen Z.,2011, Best available techniques and pollution control: a case study on China's thermal power industry. $J$. Cleaner Production, 23, 113-121.

Menz F.C. and Seip H.M., 2004. Acid rain in Europe and the United states: an update. Environ. Sci. \& Polic. 7, 253-265.

Mittal M.L.,2012. Estimates of emissions from coal fired thermal power plants in India. $20^{\text {th }}$ Emission inventory Conference

Monks P.S., Granier C., Fuzzi S., et al., 2009. Atmospheric composition change - global and regional air quality. Atm. Environ. 43, 5268-5350.

Moorthy K.K., Satheesh S.K. and Kotamarthi V.R.,2016. Evolution of aerosol research in India and the RAWEX-GVAX: an overview. Cur. Sci. 111, 53- 75.

OECD 2014 - How Was Life? Global Well-being since 1820.ISBN:9789264214262. https://doi.org/10.1787/9789264214262-en 
Olivier J. G., Greet Janssens-Maenhout G., Marilena Muntean M., Peters J. A.H.W.,2016. Trends in Global CO2 emissions: 2016 report PBL Netherlands Environmental Assessment Agency.

Prayas, 2013. Black and Dirty, the Real Challenges Facing India's Coal Sector. Prayas Energy Group, Pune, India.

Quéré L., Corinne, Andrew R. M., et al. 2017: Global Carbon Budget 2017, Earth Syst. Sci. Data Discussions.

Raghuvanshi S.P., Chandra A. and Raghav A.K.,2006. Carbon dioxide emissions from coal-based power generation in India. Environ. Conver. and Manag. 47, 427-441.

Reddy M.S. and Venkataraman C., 2002. Inventory of aerosol and sulphur dioxide emissions from India. Part II- biomass combustion. Atm. Environ. 36, 699-712.

Ritchie H. and Max Roser M., 2020. $\mathrm{CO}_{2}$ and Greenhouse Gas Emissions. Published online at OurWorldInData.org. Retrieved from: 'https://ourworldindata.org/co2-and-other-greenhousegas-emissions'.

S. J. Smith, J. van Aardenne, Z. Klimont, R. J. Andres, A. Volke, and S. Delgado Arias (2011) - Anthropogenic sulfur dioxide emissions: 1850-2005. Atmospheric Chemistry and Physics, 11, 1101-1116.

Singh R.P., Kumar S. and Singh A.K.,2018. Elevated Black Carbon Concentrations and Atmospheric Pollution around Singrauli Coal-Fired Thermal Power Plants (India) Using Ground and Satellite Data. Int. J. Environ. Res. Pub. Health. 15, 2472-2489.

Tian H., liu K., Hao Y., Gao J., Qiu P. and Zhu C., 2013. Nitrogen oxides emissions from thermal power plants in China: current status and future predictions. Environ. Sci. Technol. 47, 1135011357.

Wang S.W., Zhang Q., Streets D.G., He K.B., Martin R.V., Lamsal L.N., Chen D., Lei Y. and Lu Z., 2012. Growth in NOx emissions from power plants in China: bottom-up estimates and satellite observations. Atm. Chem. Phys. 12, 4429-4447.

WISE, 2012. Risks of Coal Based Electricity Generation in India. World Institute of Sustainable Energy, Pune, India.

World Health Organization, 2016. Ambient air pollution: A global assessment of exposure and burden of disease 